\title{
Long-Term Outcomes of a Surgical Technique in Management of Subconjunctival Orbital Fat Prolapse
}

Ken-ichi Sato ${ }^{1}$

1. Ophthalmology, Nikko Memorial Hospital, Muroran, JPN

Corresponding author: Ken-ichi Sato, vze04311@nifty.ne.jp

\section{Abstract}

\section{Objective}

This retrospective, single-center, interventional study presented the long-term results of a novel surgical technique for the management of subconjunctival orbital fat prolapse.

\section{Methods}

Nine eyes of seven consecutive patients were surgically repaired using the technique involving connective tissue repair and were intended to be followed-up for more than five years.

\section{Results}

All surgeries performed were uneventful and esthetic enhancement was achieved for each patient. No postoperative complications were noted. There was no recurrence throughout the follow-up period; six eyes of four patients were followed-up for more than five years.

\section{Conclusions}

This technique with connective tissue repair achieved good long-term results.

Received 09/14/2019

Review began 10/25/2019 Review ended 11/02/2019 Published 11/05/2019

๑) Copyright 2019

Sato. This is an open access article distributed under the terms of the Creative Commons Attribution License CC-BY 3.0., which permits unrestricted use, distribution, and reproduction in any medium, provided the original author and source are credited.
Categories: Ophthalmology, Plastic Surgery

Keywords: adipose tissue, hernia, operative procedures, orbit

\section{Introduction}

Subconjunctival orbital fat prolapse is a rare benign condition characterized by a yellowish mobile mass just below the bulbar conjunctiva, typically in the superotemporal quadrant. Patients are mostly male [1-4]. Recently, several surgical techniques for this disorder have been described, some of which are advocated as being minimally invasive [5-9]. However, knowledge of long-term results after such surgeries is still insufficient $[8,10]$.

A preliminary study of four cases presented a surgical technique for the management of subconjunctival orbital fat prolapse, attempting to avoid recurrence through connective tissue repair [11]. The study also revealed the source of the prolapsed fat as being intraconal fat. This paper reports the long-term outcomes of the cases described in the preliminary study, with three additional patients.

\section{Materials And Methods}

This was a retrospective, single-center, interventional study. Included in the study were nine eyes of seven consecutive patients who underwent surgery for subconjunctival orbital fat prolapse at Nikko Memorial Hospital from December 2003 to October 2009 (Table 1), and were intended to be followed-up for more than five years; four cases were reported on in a preliminary study [11]. 


\section{Cureus}

\begin{tabular}{|l|l|l|l|}
\hline Age at surgery (years) /Sex & Laterality & Follow-up period (years) & Reason for shortfollow-up period \\
\hline 67/Male & Bilateral & 13.8 & - \\
62/Male & Left & 12.6 & - \\
69/Male & Bilateral & 7.3 & - \\
87/Male & Left & 1.0 & Died \\
79/Male & Left & 1.3 & Follow-up defaulted \\
$70 /$ Male & Right & 0.6 & Follow-up defaulted \\
$69 /$ Male & Left & 7.9 & - \\
\hline
\end{tabular}

TABLE 1: Patients who underwent surgery for subconjunctival orbital fat prolapse.

The patients all had fat prolapse in the superotemporal quadrant with no history of trauma or surgery (Figure $1 A)$, and had a clinical diagnosis based on the report by Glover and Grove [1].

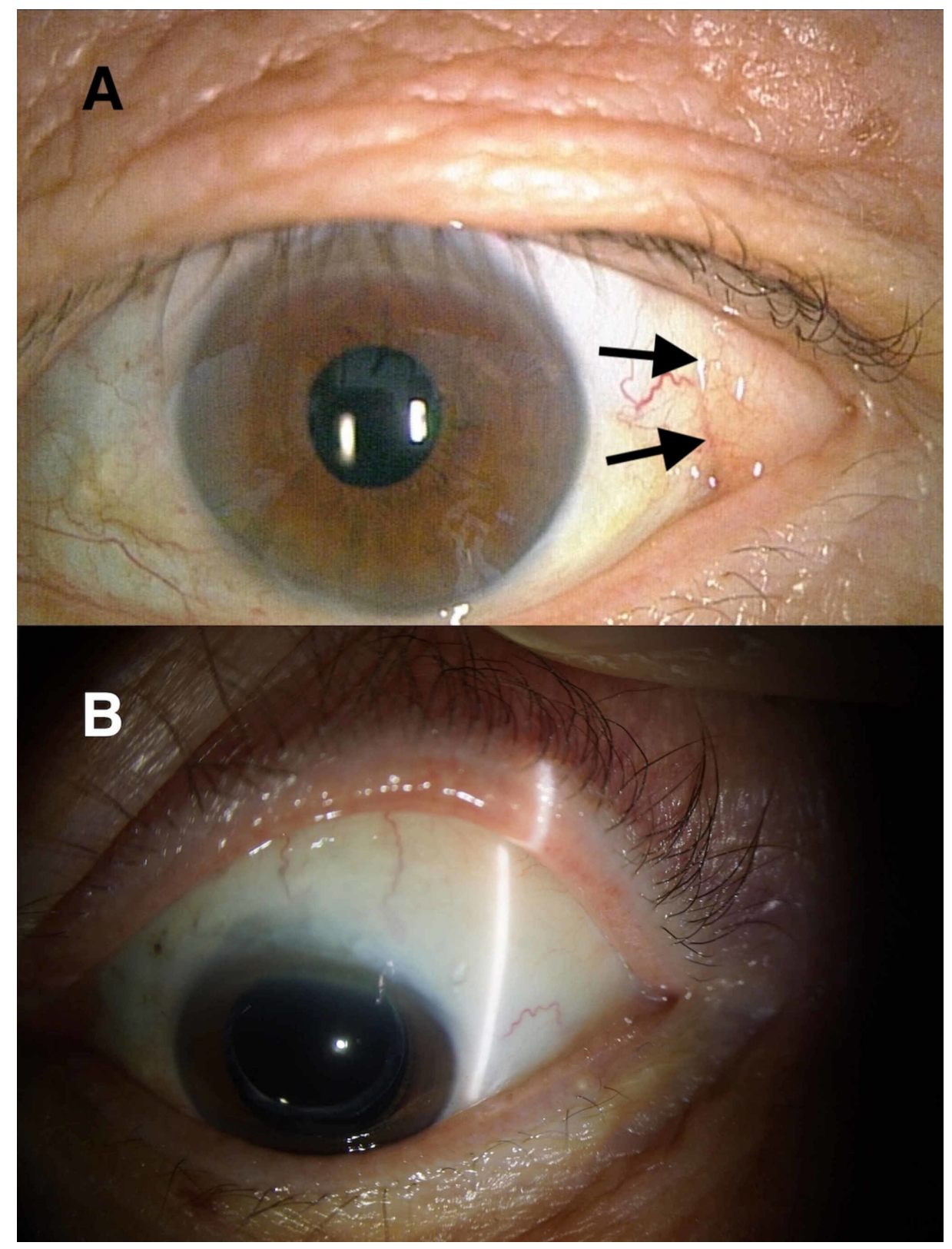




\section{Cureus}

FIGURE 1: Prolapsed subconjunctival fat in the superotemporal quadrant of the left eye of a man.

(A) Preoperative findings (69 years old). (B) Findings at 7.9 years postoperatively.

Written consent was obtained from all patients before surgery. All procedures performed in this study were in accordance with the ethical standards of the institutional research committee and with the 1964 Helsinki declaration and its later amendments or comparable ethical standards.

Details of the surgical technique (Video 1) have been fully described in the preliminary study [11].

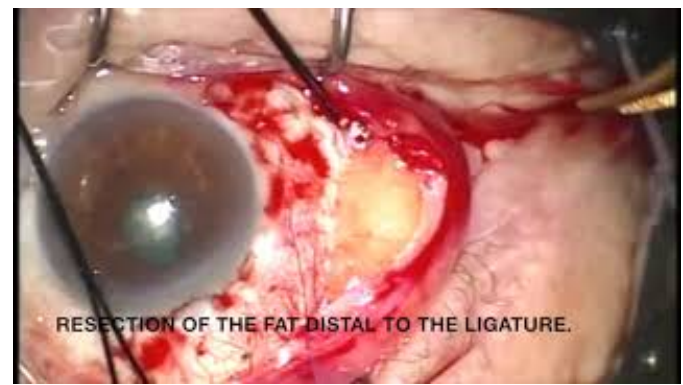

VIDEO 1: A surgical technique with connective tissue repair in the management of subconjunctival orbital fat prolapse.

View video here: https://youtu.be/-6xkE7r52rY

Briefly, a $120^{\circ}$ fornix-based conjunctival incision centered superotemporally was made under local anesthesia. The adhesion of Tenon's capsule to the limbal episclera was dissected, and the Tenon's capsule anterior to the equator was separated from the episclera. The sheet of connective tissue subsequently formed by the above procedure was everted, and the connective tissue covering the inner surface of the herniated fat was bluntly dissected to allow extrusion of the fat (Figure 2A). 


\section{Cureus}

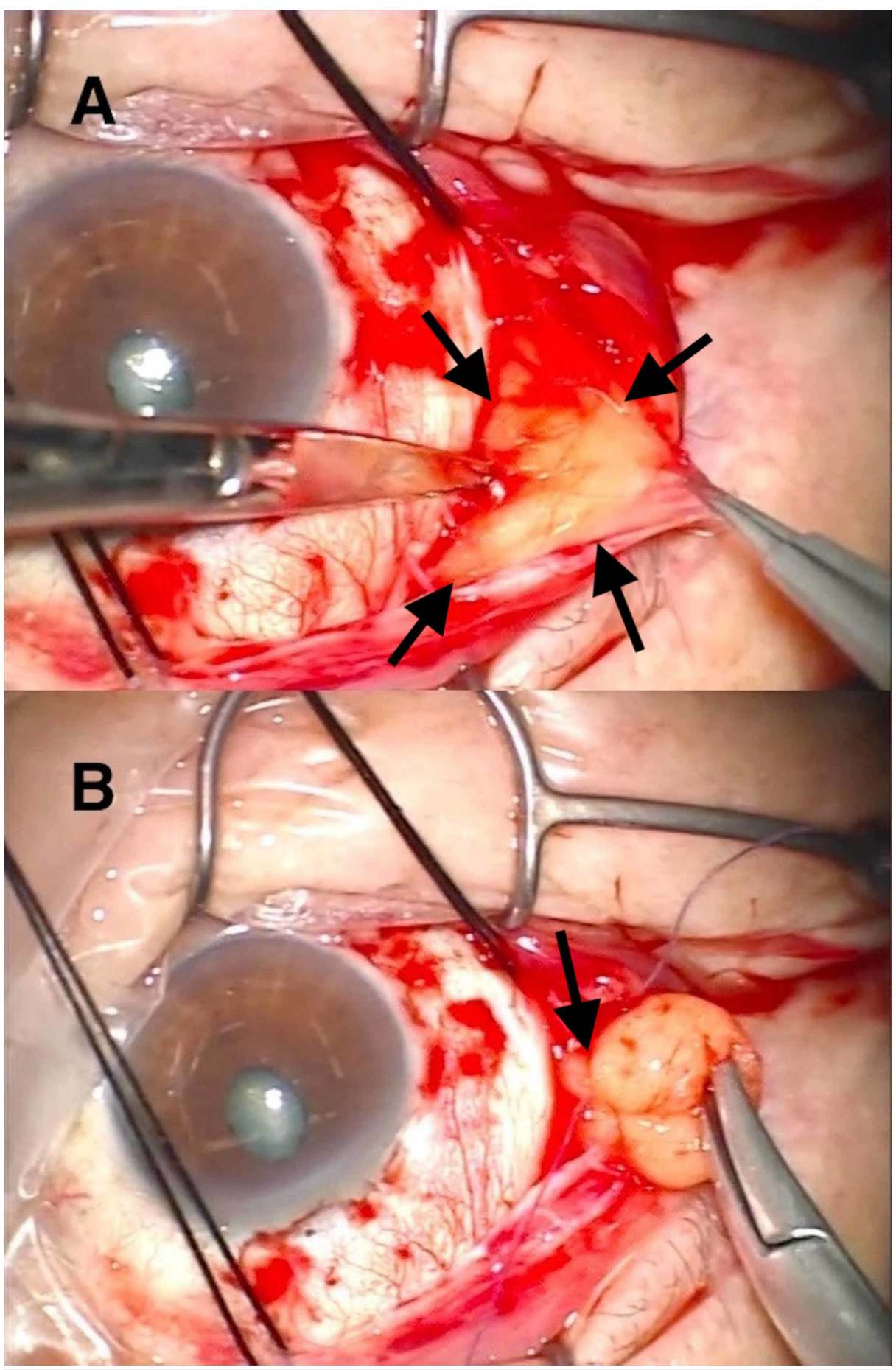

FIGURE 2: Perspective of the surgeon. Right eye of a 70 -year-old man.

(A) Fat (arrows) is extruded by blunt separation of connective tissue covering the inner surface of the fat. Note that the connective tissue is everted using forceps. (B) The base of the extruded fat is ligated (arrow).

The base of the extruded fat was ligated using a 6-0 polyglactin suture (Vicryl; Ethicon Inc., Somerville, NJ, USA) to create a pedunculated appearance (Figure $2 B$ ). Using the same ligature, the herniated fat was fixed to the episclera, 6-8 $\mathrm{mm}$ posterior to the limbus, after resection of the fat distal to the ligature. The connective tissue sheet was then repositioned on the episclera with several 6-0 polyglactin sutures, just anterior to the fixation of the fat, and the conjunctiva was subsequently closed.

Outcome measures were intra- and postoperative complications, satisfactory cosmetic results, and recurrence. 


\section{Cureus}

\section{Results}

Six eyes in four cases were followed up for more than five years (Table 1). Each surgery was uneventful and esthetic enhancement was achieved (Figure $1 B$ ). There were no postoperative complications, such as symptoms of dry-eye or impaired ocular motility due to likely muscle restriction. Also, the herniated fat was not observed in the primary eye position in all the cases throughout the follow-up period.

\section{Discussion}

The preliminary study demonstrated that the spontaneous prolapsed fat at the superior temporal quadrant stems from intraconal fat, and therefore, the anterior part of the herniated fat is covered by both the intermuscular septum and Tenon's capsule [11]. The novel technique reported in the study attempted to avoid recurrence via reconstruction of the intermuscular septae. In addition, the previous study reported initial results. The present study reports the long-term outcomes.

Although the technique is relatively complicated and invasive, it is expected to prevent recurrence better than less invasive techniques that have been previously reported (Table 2), through the added procedure of connective tissue repair [5-9]. In the present study, no recurrence occurred, even in the six eyes with observation periods of more than five years; this potentially demonstrates the robust efficacy of the technique.

\begin{tabular}{|c|c|c|c|c|c|c|c|}
\hline Author & Year & Country & $\begin{array}{l}\text { Sample } \\
\text { (eyes/patients) }\end{array}$ & Suture & Incision & $\begin{array}{l}\text { Mean follow-up period } \\
\text { (years) }\end{array}$ & $\begin{array}{l}\text { Recurrence } \\
\text { (eye[s]) }\end{array}$ \\
\hline Otaka et al. [5] & 2001 & Japan & $4 / 3$ & + & - & 1.0 & 0 \\
\hline $\begin{array}{l}\text { Sniegowski et al. } \\
\text { [6] }\end{array}$ & 2012 & U.S.A. & $4 / 3$ & - & + & 2.6 & 0 \\
\hline Nakamura et al. [7] & 2015 & Japan & $23 / 19$ & + & - & 1.6 & 1 \\
\hline Yang et al. [8] & 2017 & Korea & $48 / 37$ & + & + & 3.3 & 2 \\
\hline Raparia et al. [9] & 2018 & U.S.A. & $68 / 45$ & - & + & 3.1 & 0 \\
\hline
\end{tabular}

TABLE 2: Reports of less invasive techniques for the management of orbital fat prolapse.

This study had certain limitations. The number of patients was small and, as mentioned above, the technique is relatively invasive; the results of this technique should therefore be compared with outcomes involving less-invasive techniques in a larger study.

\section{Conclusions}

The long-term outcomes of a newly developed surgical technique with connective tissue repair for the management of subconjunctival orbital fat prolapse was presented. All subjects achieved cosmetic improvement without complications or recurrence.

\section{Additional Information}

\section{Disclosures}

Human subjects: Consent was obtained by all participants in this study. The Nikko Memorial Hospital Institutional Review Board issued approval N/A. The institutional review board did not mandate to review the protocol of this retrospective clinical study. Animal subjects: All authors have confirmed that this study did not involve animal subjects or tissue. Conflicts of interest: In compliance with the ICMJE uniform disclosure form, all authors declare the following: Payment/services info: All authors have declared that no financial support was received from any organization for the submitted work. Financial relationships: All authors have declared that they have no financial relationships at present or within the previous three years with any organizations that might have an interest in the submitted work. Other relationships: All authors have declared that there are no other relationships or activities that could appear to have influenced the submitted work.

\section{References}

1. Glover AT, Grove AS Jr: Subconjunctival orbital fat prolapse. Ophthal Plast Reconstr Surg. 1987, 3:83-86.

2. Stangos AN, Hamédani M: Spontaneous subconjunctival orbital fat prolapse: presentation of four cases . Klin Monbl Augenheilkd. 2006, 223:415-417. 10.1055/s-2006-926578 


\section{Cureus}

3. Schmack I, Patel RM, Folpe AL, et al.: Subconjunctival herniated orbital fat: a benign adipocytic lesion that may mimic pleomorphic lipoma and atypical lipomatous tumor. Am J Surg Pathol. 2007, 31:193-198. 10.1097/01.pas.0000213374.02171.0a

4. Viana GA, Osaki MH, Filho VT, Sant'Anna AE: Prolapsed orbital fat: 15 consecutive cases . Scand J Plast Reconstr Surg Hand Surg. 2009, 43:330-334. 10.1080/02844310903259124

5. Otaka I, Kyu N: A new surgical technique for the management of orbital fat prolapse . Am J Ophthalmol. 2001, 131:267-269. 10.1016/S0002-9394(00)00779-0

6. Sniegowski MC, Kelmenson A, Gregory DG, Durairaj VD: Small-incision, sutureless repair of subconjunctival fat prolapse. Ophthal Plast Reconstr Surg. 2012, 28:221-223. 10.1097/IOP.0b013e318249d5d7

7. Nakamura N, Akiyama K, Shigeyasu C, Yamada M: Surgical repair of orbital fat prolapse by conjunctival fixation to the sclera. Clin Ophthalmol. 2015, 9:1741-1744. 10.2147/OPTH.S91598

8. Yang MK, Kim N, Choung HK, Khwarg SI: Long-term outcome of conjunctival fixation sutures to the sclera for prolapsed subconjunctival orbital fat. Eye. 2017, 31:749-752. 10.1038/eye.2016.302

9. Raparia E, Rafailov L, Shinder R: In-office sutureless correction of prolapsed subconjunctival orbital fat . Ophthal Plast Reconstr Surg. 2018, 34:79-81. 10.1097/IOP.0000000000001011

10. Siban M, Weijtens O, van den Bosch W, Paridaens D: Efficacy of transconjunctival excision of orbital fat prolapse: a long-term follow-up study. Acta Ophthalmol. 2014, 92:291-293. 10.1111/aos.12032

11. Sato K, Yamaguchi T, Yokota H: A surgical technique with connective tissue repair for the management of subconjunctival orbital fat prolapse. Clin Exp Ophthalmol. 2006, 34:841-845. 10.1111/j.14429071.2006.01391.x 